\title{
70th Annual Meeting
}

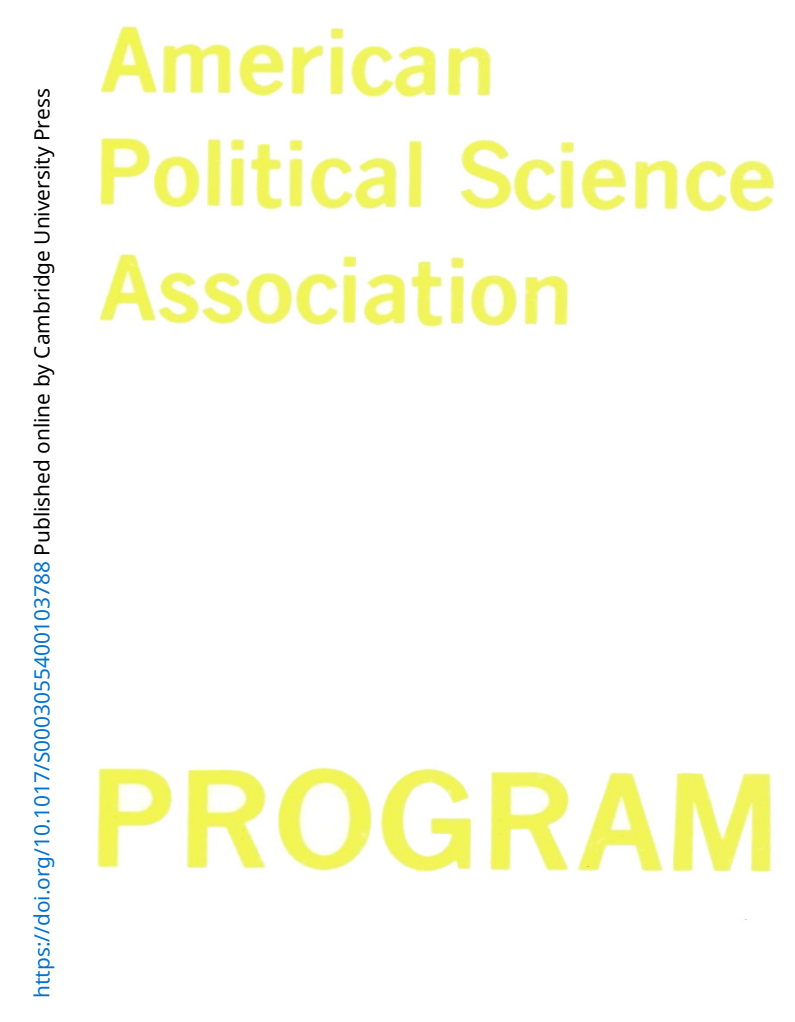




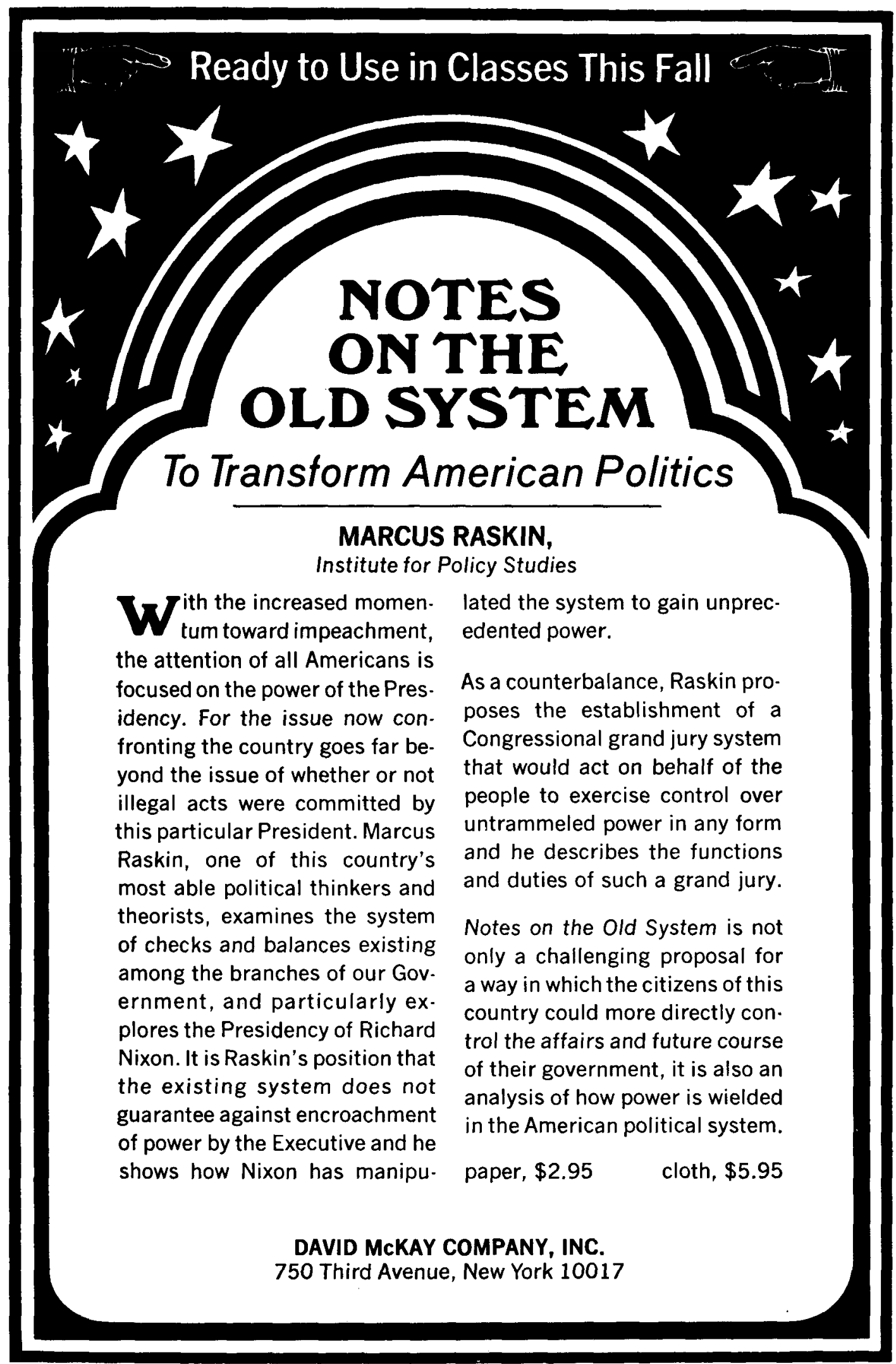




\section{NEW FROM ILLINOIS IN '74}

\section{A DISCOURSE ON STATESMANSHIP}

The Design and Transformation of the American Polity

Paul Eidelberg. In this revolutionary treatise Eidelberg aims to generate a new school of statesmanship, advance a new interpretation of American political history, and prepare the grounds for a synthesis of classical and modern political science.

420 pp. $\$ 16.00$.

\section{QUANTITATIVE SOCIAL SCIENCE RESEARCH ON LATIN AMERICA}

edited by Robert $S$. Byars and Joseph L. Love. This guidebook to research on Latin America offers evaluations of relevant studies and indicates critical areas for new research. An appendix describes 16 data banks with Latin American materials. ". . . fills a considerable void."-Orbis. 275 pp. $\$ 8.95$.

\section{EMERGENCE OF THE PRESIDENTIAL NOMINATING CONVENTION, 1789-1832}

James $S$. Chase. Analyzes the circumstances which led to the establishment of the presidential nominating convention as the authoritative decisionmaking agency for political parties in the United States. $\quad 349$ pp. $\quad \$ 8.95$.

\section{NATIONAL PARTY PLATFORMS, 1840-1972}

FIFTH EDITION

compiled by Donald Bruce Johnson and Kirk H. Porter. The answer to virtually any question about national party platforms can be found in this up-to-date volume containing authenticated copies of platforms of all the major parties and the principal minor ones.

890 pp. $\$ 20.00$.

from the series STUDIES IN ILLINOIS CONSTITUTION MAKING

\section{POLITICS OF THE PURSE}

Revenue and Finance in the Sixth Illinois Constitutional Convention

Joyce C. Fishbane and Glenn W. Fisher. The forces behind decision-making in the constitutional convention are analyzed in this study of Illinois' new revenue and finance articles. $232 \mathrm{pp}$. Paper, \$3.45. Fall '74.

\section{BALLOTS FOR CHANGE}

New Suffrage and Amending Articles for Illinois

Alan S. Gratch and Virginia H. Ubik. Two staff members of the 1970 Illinois Constitutional Convention discuss the meaning and impact of the amending and suffrage articles finally adopted, and analyze the lessons to be learned from the experience. 136 pp. Paper, \$3.45.

THESE AND OTHER TITLES ARE ON DISPLAY AT BOOTH 11. 


\author{
President \\ AVERY LEISERSON \\ Vanderbilt University \\ President-Elect \\ AUSTIN RANNEY \\ University of Wisconsin \\ Madison \\ Vice Presidents \\ SUZANNE RUDOLPH \\ University of Chicago \\ DANKWART A. RUSTOW \\ CUNY (Brooklyn) \\ JOHN WAHLKE \\ University of lowa
}

\author{
Secretary \\ SAMUEL H. BARNES \\ University of Michigan \\ Treasurer \\ CHARLES O. JONES \\ University of Pittsburgh \\ Program Chairman \\ SAMUEL C. PATTERSON \\ University of lowa \\ Executive Director \\ EVRON M. KIRKPATRICK \\ 1527 New Hampshire Avenue, N.W. \\ Washington, D.C. 20036 \\ Managing Editor, APSR \\ NELSON W. POLSBY \\ University of California \\ Berkeley
}

\section{COUNCIL}

(Above-named Officers ex officiis)

1973-74

PAUL Y. HAMMOND

Rand Corporation

DONALD G. HERZBERG

Georgetown University

MATTHEW HOLDEN, JR.

University of Wisconsin, Madison ROBERT H. HORWITZ

Kenyon College

WILLIAM S. LIVINGSTON

University of Texas at Austin

H. MARK ROELOFS

New York University

ROBERTA S. SIGEL

Rutgers University

SIDNEY WISE

Franklin and Marshall College
1974.75

LUCIUS J. BARKER

Washington University, St. Louis MARTIN DIAMOND

Northern IIlino is University ADA W. FINIFTER

Michigan State University

STANLEY HOFFMANN

Harvard University

THEODORE J. LOWI

Cornell University

FRANCINE RABINOWITZ

Massachusetts Institute of Technology SIDNEY VERBA

Harvard University

AARON WILDAVSKY

University of California, Berkeley

\section{FORMER PRESIDENTS}

FRANK J. GOODNOW

ALBERT SHAW

FREDERICN. JUDSON

JAMES BRYCE

A. LAWRENCE LOWELL

WOODROW WILSON

SIMEON E. BALDWIN

ALBERT BUSHNELL HART

W. W. WILLOUGHBY

JOHN BASSETT MOORE

ERNST FREUND

JESSE MACY

MUNROE SMITH

HENRY JONES FORD

PAUL S. REINSCH

LEO S. ROWE

WILLIAM A. DUNNING

HARRY A. GARFIELD

JAMES W. GARDNER

CHARLES E. MERRIAM

CHARLES A. BEARD

WILLIAM B. MUNRO

JESSE S. REEVES
JOHN A. FAIRLIE

BENJAMIN F. SHAMBAUGH

EDWARD S. CORWIN

WILLIAM F. WILLOUGHBY

ISIDOR LOEB

WALTER J. SHEPARD

FRANCIS W. COKER

ARTHUR N. HOLCOMBE

THOMAS REED POWELL

CLARENCE A. DYKSTRA

CHARLES GROVE HAINES

ROBERT C. BROOKS

FREDERICK A. OGG

WILLIAM ANDERSON

ROBERT E. CUSHMAN

LEONARD D. WHITE

JOHN M. GAUS

WALTER F. DODD

ARTHUR W. MACMAHON

HENRY R. SPENCER

QUINCY WRIGHT

JAMES K. POLLOCK

PETER H. ODEGARD
LUTHER H. GULICK PENDLETON HERRING RALPH J. BUNCHE CHARLES MCKINLEY HAROLD D. LASSWELL E. E. SCHATTSCHNEIDER V. O. KEY, JR R. TAYLOR COLE CARL B. SWISHER EMMETTE S. REDFORD CHARLES S. HYNEMAN CARL J. FRIEDRICH C. HERMAN PRITCHETT DAVID B. TRUMAN GABRIEL A. ALMOND ROBERT A. DAHL MERLE FAINSOD DAVID EASTON KARL W. DEUTSCH ROBERT E. LANE HEINZ EULAU ROBERT E. WARD 


\title{
PROGRAM
}

\author{
of the
}

\section{Seventieth}

\section{Annual Meeting}

The American Political Science Association

AUGUST 29 - SEPTEMBER 2, 1974

PALMER HOUSE

CHICAGO, ILLINOIS 